\title{
Canine visceral leishmaniasis in São José de Ribamar, Maranhão State, Brazil
}

\author{
K.S. Guimarães ${ }^{a}$, Z.S. Batista ${ }^{a}$, E.L Dias ${ }^{\text {b }}$, R.M.S.N.C. Guerra ${ }^{\mathrm{b}}$, \\ A.D.C. Costa ${ }^{\mathrm{b}}$, A.S. Oliveira ${ }^{\mathrm{b}}$, K.S. Calabrese ${ }^{\mathrm{c}}$, F.O. Cardoso ${ }^{\mathrm{c}}$, \\ C.S.F. Souza ${ }^{\mathrm{c}}$, T. Zaverucha do Vale ${ }^{\mathrm{c}}$, S.C. Gonçalves da Costa ${ }^{\mathrm{c}}$, \\ A.L. Abreu-Silva ${ }^{\mathrm{b}, *}$

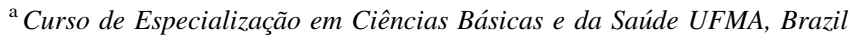 \\ ${ }^{\mathrm{b}}$ Departamento de Patologia, Universidade Estadual do Maranhão, Cidade Universitária Paulo VI, \\ Caixa Postal 09 Tirirical, São Luís-Maranhão CEP 65055-150, Brazil \\ ${ }^{\mathrm{c}}$ Laboratório de Imunomodulação, Depto de Protozoologia do Instituto Oswaldo Cruz/FIOCRUZ, Brazil
}

Received 5 April 2005; received in revised form 9 May 2005; accepted 11 May 2005

\begin{abstract}
Here, we describe the situation of canine visceral leishmaniasis in two villages of São José de Ribamar in Maranhão State/ Brazil, where human cases have been registered. Blood samples of 36 household crossbred dogs from Sergio Tamer village and 43 dogs from Quinta village were collected and the serum used for serological diagnosis. An Indirect Fluorescent Antibody Test (IFAT) and enzyme-linked immunosorbent assay (ELISA) were used to detect antibodies against Leishmania. The clinical examination showed that $25 \%$ of the canine population of Quinta presented a poor body condition and in 39\%, ectoparasites (ticks and fleas) were detected. In both tests, serology revealed that $21 \%$ (9 out of 43) of the dogs presented antibodies against Leishmania (55\% were asymptomatic and $45 \%$ were symptomatic). In the Vila Sérgio Tamer, $25 \%$ (9 out of 36) of the dogs were seropositive for Leishmania ( $66.67 \%$ were asymptomatic and $33.33 \%$ were symptomatic), $33 \%$ presented poor body condition, and $22 \%$ have ectoparasites. The clinical signs more frequent were skin lesions. The statistical analysis showed that there was no statistical difference $(p>0.05)$ between the seropositivity of the dogs from the two villages. The same was observed when the clinical signs were compared $(p>0.05)$. Both villages have favorable conditions to maintain the cycle of leishmaniasis.

(C) 2005 Elsevier B.V. All rights reserved.
\end{abstract}

* Corresponding author. Tel.: +55 983252 0607; fax: +55 9832455882 .

E-mail address: anabreu@ioc.fiocruz.br (A.L. Abreu-Silva).

\section{Introduction}

American visceral leishmaniasis (AVL) is a chronic and wasting disease characterized by the infection of the mononuclear phagocytes by Leishmania chagasi 
(Cunha and Chagas, 1937; Herwaldt, 1999). Although AVL occurs from Mexico to Argentina (Grimaldi et al., 1989), over $90 \%$ of the human cases come from Brazil, especially from the Northeast region of the country.

The first report of $L$. chagasi in Brazil was made by Penna (1934) during histological examination of liver specimens though post-mortem viscerotomy. Soon after, Chagas et al. (1937, 1938) observed cases of AVL in domestic dogs. Later, wild reservoirs represented by the foxes Lycalopex vetulus (Deane and Deane, 1954a,b) and Cerdocyon thous (Lainson et al., 1969; Silveira et al., 1982) were also reported.

Transmission from human to human is found in visceral leishmaniasis caused by L. donovani and it is prevalent in India and Sudan (Zijlstra and El-Hassan, 2001).

In this way, it is indispensable to detect infected dogs and to understand the role of asymptomatic dogs as reservoirs, as they are often undetectable upon clinical examination and a large number escape from control measures, thus contributing to the spread of leishmaniasis. Information on the geographical distribution and prevalence of canine AVL is essential to the design and implementation of appropriate control measures (Campino, 2002).

This paper describes the situation of AVL in two villages of São José de Ribamar in Maranhão State/ Brazil, where human cases have been registered. Despite that leishmaniasis be a serious public health problem in Maranhão State, the seroprevalence of canine visceral leishmaniasis is underestimated.

\section{Materials and methods}

\subsection{Description of the area}

São José de Ribamar in São Luís Island, is a municipality located between $2^{\circ} 37^{\prime} 30^{\prime \prime} \mathrm{S}$ and $44^{\circ} 07^{\prime} 30^{\prime \prime} \mathrm{L}$, in the north region of the Maranhão State/Brazil. It has a hot climate with annual average temperature around $26{ }^{\circ} \mathrm{C}$. The population is approximately 107,333 inhabitants distributed in several villages. The municipality is recovered by a type of seasonally forest vegetation-Forest seasonally Perenifolia comprised mainly by babaçu palm tree
(Orbignya speciosa) and it also has forest Perenifolia Paludosa Maritime - Manguezal (mangrove swamp). The original vegetation was modified, due to intense human occupation in the area and nowaday "capoeiras" replaced the original vegetation although babaçu palm trees are still present (Maranhão, 2002). This work was done in Vila Sérgio Tamer and Quinta villages in which recent cases of human visceral leishmaniasis were notified. The Vila Sérgio Tamer has 586 residences and 1541 inhabitants and Quinta has 545 residences and 1435 inhabitants. The sanitary conditions are low (open sewage, no water sanitation and poor housing). In opposition to Vila Sérgio Tamer, in the last village, the residences consist mainly of small ranches.

\subsection{Survey design}

Household mongrel dogs from two villages Sérgio Tamer (24 males and 12 females) and Quinta (26 males and 17 females) were examined for clinical symptoms of AVL. Dogs were examined for poor body condition and clinical picture. The clinical signs were scored as follows: score 0 (no clinical signs), score 1 (skin lesions: ulcers, alopecia, desquamation, onychogryphosis) score 2 (visceral signs: lymph adenopathy), and score 3 (skin lesions + visceral signs).

The dogs sampled were the ones that live in streets where human cases of visceral leishmaniasis have occurred. Peripheral blood samples were collected by cephalic vein puncture and the serum was separated, stored at $-20{ }^{\circ} \mathrm{C}$ until serological diagnosis. An Indirect Fluorescent Antibody Test (IFAT) and enzyme-linked immunosorbent assay (ELISA) were used to detect antibodies using a commercial kit for canine leishmaniasis provided by Biomanguinhos/ FIOCRUZ. The threshold serum dilution for a positive test was 1:40 and the final dilution was 1:1280. For ELISA a sample was considered positive if the optical density was 2.6 times higher than the standard deviation of the control group.

\subsection{Statistical analysis}

The chi-square test was used to compare the clinical score and serology between the two villages. The relationship was considered significant when $p<0.05$. 


\section{Results}

Habitations of both villages, Quinta and Vila Sérgio Tamer, have minimal infrastructure and sanitation conditions are precarious. Household crossbreed dogs are kept outdoors during the day, are not well fed, do not received vaccines nor veterinary assistance. The clinical examination showed that $25 \%$ of the canine population of Quinta presented a poor body condition and in $39 \%$, ectoparasites (ticks and fleas) were detected. The serology revealed that $21 \%$ (9 out of 43 ) of the dogs presented antibodies against Leishmania (55\% were asymptomatic and $45 \%$ were symptomatic). In these symptomatic animals, the clinical signs more frequent were skin lesions (ulcer in the pina, alopecia, onychogryposis, and dry desquamation). In the Vila Sérgio Tamer, $25 \%$ (9 out of 36) of the dogs were seropositive for Leishmania $(66.67 \%$ were asymptomatic and $33.33 \%$ were symptomatic), $33 \%$ presented poor body condition and $22 \%$ had ectoparasites (ticks and fleas). The clinical signs more frequent were alsoskin lesions. The statistical analysis showed that there was no statistical difference $(p>0.05)$ between the seropositivity of the dogs from the two villages. The same was observed when the clinical score 0 and 1 were compared $(p>0.05)$. No animal presented clinical signs for score 2 and only one animal from Sérgio Tamer village showed signs for score 3. Serological titers by indirect immunofluorescence test ranged from $1 / 40$ to $1 / 640$. There was no difference between the serological tests used.

\section{Discussion}

The Vila Sérgio Tamer and Quinta could be a risk area for leishmaniasis maintenance since positive cases of human and canine leishmaniasis had been detected and the vector, Lutzomyia longipalpis, is commonly captured in the area according to previous entomological studies (Carvalho et al., 2000). Both villages have minimal infrastructure associated to intense urbanization in the last years. The native vegetation (moist tropical broadleaf forest) is being gradually replaced by secondary-growth forest called "capoeira". This can contributed to the establishment of the sand fly vector in the peridomestic and intradomiciliary habits. Urbanization clearly appears to be one of the major worldwide risk factors for leishmaniasis and largely contributes to the persistence of the burden of the disease especially in anthroponotic foci (Desjeux, 2002).

Since the first studies about visceral leishmaniasis, dogs have been incriminated as the most important urban reservoir of the disease (Deane, 1956; Alencar, 1961). However, the culling of infected dogs had not been enough to control the disease in endemic areas, such as, São Luís Island where canine seroprevalence remains underestimated. Previous studies showed that in other village of the same municipality, the canine seroprevalence was 64\% (Melo et al., 2002). Here, it was observed that the seroprevalence was $21 \%$ (Quinta) and 25\% (Vila Sérgio Tamer), although it is lesser when compared with previous study, the risk for leishmaniasis remains high. The difference in seroprevalence can be observed not only in this municipality but also in another endemic areas in Brazil as demonstrated by Alves et al. (1998) who observed a seroprevalence of $1.59 \%$ among dogs from Fortaleza/Ceará. França-Silva et al. (2003), in Montes Claros/Minas Gerais, detected 9.7\%, Cabrera et al. (2003) found out $25 \%$ of seropositivity in dogs of Barra de Guaratiba/Rio de Janeiro, Guerra et al. (2004) detected $10.3 \%$ in Roraima and Cortada et al. (2004), observed a seroprevalence of $75.3 \%$ among dogs from Anastácio/Mato Grosso do Sul.

In dogs, the clinical picture of this disease is characterized by skin lesions (dry desquamation, alopecia and muzzle ulcer), hepatomegaly, splenomegaly, weight loss, generalized lymphoadenopathy, ocular lesions, and onycogriphosis (Ferrer et al., 1988; Cortada et al., 2004). Here, it was also observed that in both areas, the more frequent clinical signs were skin lesions, which suggests that in dogs, L. chagasi or $L$. infantum primarily induces cutaneous lesions and after that it spreads to internal organs.

Our findings are in agreement with Ferrer et al. (1991) and Campino (2002) that state that the great majority of dogs infected by Leishmania remain asymptomatic. We found out $61 \%$ of asymptomatic dogs in both villages. The presence of latent infections in dogs is typical and important in maintaining the long-term presence of the parasite in endemic areas (Palatinik-de-Sousa et al., 2003).

In conclusion, both environmental and ecological aspects, may have contributed to the increase in VL 
incidence in the municipality of São José de Ribamar since, in the last years, there were expansion of villages, the establishment of new settlements, and increased agricultural activity. These conditions have led to an increase in refuse and solid waste providing good habitats for sand fly vectors and also attracting stray dogs and wild canid reservoir hosts.

\section{Acknowledgment}

Mr. Erisvaldo Montes dos Santos of FUNASA for technical assistance with canine survey. This work was supported by grants from CNPq and Instituto Oswaldo Cruz/Ministery of Health, Brazil. It was performed in accordance with Ethical Procedures (IOC/P0062/00).

\section{References}

Alencar, J.E., 1961. Profilaxia do calazar no Ceará Brasil. Revista do Instituto Medicina Tropical de São Paulo 25, 203-252.

Alves, A.L., Bevilaqua, M.L., Moraes, N.B., Franco, S.O., 1998. Levantamento epidemiológico da leishmaniose visceral em cães vadios da cidade de Fortaleza. Ceará. Ciência Anim. 8, 63-68.

Cabrera, M.A.A., Paula, A.A., Camacho, L.A.B., Marzochi, M.C.A., Xavier, S.C., Silva, A.V.M., Jansen, A.M.A., 2003. Canine visceral leishmaniasis in Barra de Guaratiba, Rio de Janeiro Brazil: assessment of risk factors. Revista do Instituto Medicina Tropical de São Paulo 45, 79-83.

Campino, L.M., 2002. Reservoirs and leishmaniasis: epidemiology and Disease. In: Farrel, J.P. (Ed.), Leishmania. Wold Class Parasites. Kluwer Academic Publishers, pp. 45-57.

Carvalho, M.L., Rebêlo, J.M.M., Araújo, J.A.C., Barros, V.L.L., 2000. Aspetos ecológicos dos flebotomíneos (Diptera, Psychodidae) do município de São José de Ribamar, ilha de São Luís, MA, Brasil. Entomologia y Vetores 7, 19-32.

Chagas, E., Cunha, A.M., Castro, G.O., Ferreira, L.C., Romana, C., 1937. Leishmaniose visceral americana (Nova entidade mórbida do homem na América do Sul) Relatório dos trabalhos realizados pela comissão encarregada do estudo em leishmaniose visceral americana em 1936. Memórias do Instituto Oswaldo Cruz 32, 321-390.

Chagas, E., Cunha, A.M., Ferreira, L.C., Deane, L.M., Deane, G.M., Guimarães, F.N., Paumgarten, M.J. von, Sá, B., 1938. Leishmaniose visceral americana (Relatório dos trabalhos realizados pela comissão encarregada do estudo em leishmaniose visceral americana em 1937). Memórias do Instituto Oswaldo Cruz 33, 89 229.

Cortada, V.C.M.L., Dova, M.E.C., Souza lima, M.A.A., Oshiro, E.T., Menezes, C.R.V., Abreu-Silva, A.L., Cupolilo, E., Souza, C.S.F., Cardoso, F.O., Zaverucha do valle, T., Brazil, R.P., Calabrese, K.S., Gonçalves da costa, 2004. Canine visceral leishmaniosis in Anastácio, Mato Grosso do Sul State Brazil. Vet. Res. Commun. 28, 365-474.

Cunha, A.M., Chagas, E., 1937. Nova espécie de protozoário do gênero Leishmania patogênico para o homem (nota prévia). O Hospital 11, 5-9.

Deane, L.M., Deane, M.P., 1954a. Encontro de Leishmania nas vísceras e na pele de uma raposa, em zona endêmica de calazar, nos arredores de Sobral no Ceará. O Hospital 45, 419-421.

Deane, L.M., Deane, M.P., 1954b. Infecção experimental do Phlebotomus longipalpis em raposa (Lycalopex vetulus) naturalmente parasitada pela Leishmania donovani. O Hospital 46, 651-653.

Deane, L.M., 1956. Leishmaniose visceral no Brasil. Estudo sobre reservatórios e transmissores realizados no Estado do Ceará. Ser. Nac. Educ. Sanit. Thesis Doctorade, Rio de Janeiro, 162 pp.

Desjeux, P., 2002. Urbanization of the Leishmaniasis. In: Proceedings of the Second International Canine Leishmaniasis Fórum, Spain, pp. 49-55.

Ferrer, L., Rabanal, R., Fondevila, D., Ramos, J.A., Domingo, M., 1988. Skin lesions in canine leismaniasis. J. Small Anim. Pract. 29, 389-396.

Ferrer, L., Juanola, B., Ramos, J.A., Ramis, A., 1991. Chronic colitis due to Leishmania infection in two dogs. Vet. Pathol. 28, 242243.

França-Silva, J.C., da Costa, R.T., Siqueira, A.M., Machado-Coelho, G.L., da Costa, C.A., Mayrink, W., Vieira, E.P., Costa, J.S., Genaro, O., Nascimento, E., 2003. Epidemiology of canine visceral leishmaniosis in the endemic area of Montes Claros Municipality, Minas Gerais State, Brazil. Vet. Parasitol. 111, 161-173.

Grimaldi jr, G., Tesh, R.B., Mcmahon-Pratt, D., 1989. A review of the geographic distribution and epidemiology of leishmaniasis in the New World. Am. J. Trop. Med. Hyg. 41, 687-725.

Guerra, J.A.O., Barros, M.L.B., FÉ, N.F., Guerra, M.V.F., Castellon, E., Paes, M.G., Sherlock, I.A., 2004. Leishmaniose visceral entre índios no Estado de Roraima Brasil. Aspectos clínico epidemiológicos de casos observados no período de 1989 a 1993. Revista da Sociedade Brasileira de Medicina Tropical 37, 305311.

Herwaldt, B.L., 1999. Leishmaniais. Lancet 354, 1191-1199.

Lainson, R., Shaw, J.J., Lins, Z.C., 1969. Leishmaniasis in Brazil: IV. The fox Cerdocyon thous (L.) as a reservoir of Leishmania donovani in Para state. Brazil. Trans. R. Soc. Trop. Med. Hyg. 63, 741-745.

Maranhão, 2002. Gerência de planejamento e desenvolvimento econômico, laboratório de geoprocessamento-UEMA, São Luís, GEPLAN.

Melo, F.A., Pereira, J.G., Calabrese, K.S., Abreu-Silva, A.L., 2002. Seroprevalence of canine visceral leishmaniasis and Chagas' disease in Vila São José-São José de Ribamar. Maranhão State. Revista do Instituto de Medicina Tropical de São Paulo 12 (Suppl.), 130.

Palatinik-de-Sousa, C.B., Santos, W.R., França-Silva, J.C., Costa, R.P., Reis, A.B., Palatinik, M., Mayrink, W., Genaro, O., 2003. Impact of canine control on the epidemiology of canine and human visceral leishmaniasis in Brazil. Am. J. Trop. Med. Hyg. 65, 510-517. 
Penna, H.A., 1934. Leishmaniose visceral no Brasil. Brasil Médico 48, 949-950.

Silveira, F.T., Lainson, R., Shaw, J.J., Póvoa, M.M., 1982. Leishmaniasis in Brazil: XVIII Further evidence incriminating the fox Cerdocyon thous (L.) as a reservoir of Amazonian vis- ceral Leishmaniasis. Trans. R. Soc. Trop. Med. Hyg. 76, 830-832.

Zijlstra, E.E., El-Hassan, A.M., 2001. Leishmaniasis in Sudan Visceral leishmaniasis. Trans. R. Soc. Trop. Med. Hyg. 95 (Suppl.), S27. 